\title{
Professional competency: Pre-service mathematics teachers' understanding toward probability concept
}

\author{
Sitti Karimah Sulfiah ${ }^{1}$, Yus Mochamad Cholily ${ }^{1}$, Agus Subaidi*2 \\ ${ }^{1}$ Department of Mathematics Education, Muhammadiyah University of Malang, Indonesia \\ ${ }^{2}$ Department of Mathematics Education, Madura University, Indonesia \\ *Corresponding author: agus math@unira.ac.id
}

\section{ARTICLE INFO}

Article history:

Received: 26 February 2021

Revised: 9 June 2021

Accepted: 10 June 2021

Published online: 29 June

2021

Published regularly: July 2021

Keywords:

Conceptual understanding, mathematical ability, probability

\begin{abstract}
The ability to understand mathematics is a faculty crucial to be possessed by pre-service teachers who will enter into the education sphere. It is one of the professional competencies essential for teachers since satisfactory lessons' delivery engenders more comprehensible instruction in teachers' students. Qualitative research employs a descriptive approach relevant to the research purpose, describing mathematics pre-service teachers' professional competency of understanding the concept toward probability observed based on mathematical abilities; advanced, intermediate, and basic mathematics ability. The subjects are three preservice teachers having passed discrete mathematics course in a college in Madura. The criteria to select the subjects are the GPA (Grade-point Average) of the last semester and information from the lecturer. It is because unlikely to administer the test due to online learning applied at the college. Findings indicated that the subject with advanced mathematics ability could meet individual concepts, relate concepts and connect concepts with the operations. The subject with intermediate mathematics ability could meet individual concepts, but could not relate to some concepts. However, he could connect concepts with the operations. The subject with basic mathematics ability could not meet individual concepts, relate concepts, and connect concepts with the operations. In terms of the advancement indicator of understanding the concept, the subjects have not attained it since they have not apprehended concept definition well, particularly the probability concept, although the subject with advanced mathematics ability was procedurally prodigious.
\end{abstract}

(C) 2021 Universitas Muhammadiyah Surakarta

\section{Introduction}

Probability as one of mathematics lessons which is fundamental in mathematics curriculum in the world (Elbehary, 2020) is used for the learning material from primary education to higher education as the fulfillment of students' needs when students confront with a problem (Batanero, 2020). Additionally, it becomes one of content standards which should be mastered by students (NCTM, 2000). In addition, it is one of contexts examined in PISA to assess mathematical literacy (OECD, 2016). Probability is a challenging lesson for students especially in compound events. They tend to make incorrect predictions of events

To cite this article:

Sulfiah, S. K., Cholily, Y. M., \& Subaidi, A. (2021). Professional competency: Pre-service mathematics teachers' understanding toward probability concept. JRAMathEdu (Journal of Research and Advances in Mathematics Education), 6(3), 206-220. https://doi.org/10.23917/jramathedu.v6i3.13779 
(Abrahamson, 2014) so that many students have difficulty learning probability. They find it tricky to connect theoretical and empirical contexts (Nilsson, 2014).

In general, there are some difficulties confronted by students when solving the problem of probability. These are combination contents, binomial probability comparisons, product rules, and general problems of binomial probability (Sánchez \& Landín, 2014). Several aspects leading to students' difficulties in resolving probability problems are due to the lack of concept understanding, patterns, and motivation for doing probability lessons (Putridayani \& Chotimah, 2020; Sánchez \& Landín, 2014). Based on the previous research conducted by Williams dan Nisbet (2014) that there is a positive correlation among attitudes, beliefs, and students' probability concept understanding. The fundamental problem of understanding probability concepts that students should master is obtained in its understanding and the relationship between probability lessons and other mathematical aspects (Brase, Martinie, \& Castillo-Garsow, 2014; Savard, 2014).

One of the factors influencing students' learning is teachers. However, teachers' competency still lacks at solving the problems of probability (Batanero, Contreras, Díaz, \& Sánchez, 2015), even though, according to the latest research conducted by Estrada and Batanero ( $\underline{2020})$ that a teacher had performed a positive attitude towards probability lessons and his instruction was acceptable. To perform effective learning, teachers need to master general and specific content knowledge of probability (Groth, 2010). Hence, based on some previous research, it is fascinating to research anew to achieve more credible results concerning pre-service teachers' understanding of concept based on the current research result.

There have been several previous studies regarding the ability to understand mathematical concepts of prospective teachers such as the relationship between student final grades and understanding of mathematical conceptsconducted by Faradillah (2018), and investigation of students' errors in completing probability lessons by Indriani ( $\underline{2020})$. However, Indriani's studies only focus and discuss student mistakes in solving a problem in probability. She did not discuss the cause of student mistakes and how the students' understanding of mathematical concepts affects them to make the mistakes. Besides, the understanding of mathematical concepts is very important for pre-service mathematics teachers..

Based on the problem analyzed, this research aims to describe pre-service teachers' professional competency in probability lessons as vessels that will enter into school to educate and teach students since teachers in education 4.0 should possess professional competency (Zulfitri, Setiawati, \& Ismaini, 2019). Besides, teachers' profile implicates in building students' concepts (Yuliyanti, Winarso, \& Misri, 2019), especially the ability of understanding concepts now that it will influence other competencies of teachers (Yilmaz, 2020). However, the competency that will be researched is limited to the understanding concept in probability lessons as the quality of concept understanding determines the learning effectiveness that needs to be considered (Afriyani, Sa'dijah, Subanji, \& Muksar, 2018). Furthermore, the fundamental basis for solving the problem is that apprehending the concept underlying a problem can adopt an appropriate resolution strategy (Sundary, Jatmiko, \& Widyastuti, 2020). The probability lesson, especially in combinatorics, is vital to be optimized or mastered by all grades (Ihsan \& Kosasih, 2018). 


\section{Research Method}

This research employs a qualitative research method with a descriptive approach since it aims to describe the pre-service teachers' professional competency of understanding concepts towards probability lessons observed based on mathematical ability. The subjects of this research are three college students of mathematics education who have passed discrete mathematics. Each of them has advanced, intermediate, and basic mathematics ability in a college in Madura. The three subjects are mathematics preservice teachers who will enter into mathematics later on and teach students, especially probability lessons. The determination of subjects utilizes the purposive sampling technique. Several things considered in naming the subjects are the GPA (Grade-point Average) of the last semester and information from the in-charge lecturer since it is unlikely to administer a subject election test due to online learning applied at the college; hence it is improbable to face to face.

These research instruments are worksheets and interview guidance. The worksheet was used to know the pre-service teachers' professional competency towards combinatorics lessons observed based on mathematical ability. The used worksheet contained one question of probability. It was validated by two mathematics experts (Discrete Mathematics lecturer) and an experienced mathematics teacher who teaches in one of schools in Madura and It is deemed valid to become a research instrument. The validation used included content validity, language and question writing, and the suitability of the questions with indicators of the ability to understand mathematical concepts. Each validator performs the same validation according to these points to be more sure of the instrument's validity. Meanwhile, the guidance of a semi-structural interview was employed to determine more thorough information and more relied on the credibility of data result to obtain a conclusion.

Methodological triangulation is used to check data validity, namely giving written tests and interviewing with the subject to get valid data. The phases employed in data analysis correspond to the steps of qualitative research. These are data reduction, data presentation, and concluding. Afterward, the test results conducted by the subjects and the interview transcript are reduced, the data which are reputedly imperative are presented in the research result and discussion, then the conclusion obtained. To determine the preservice teachers' professional competency, the indicator used in this research refers to Jin and Wong (2015) that is an individual concept, connecting some concepts and relating the concept to its operation. In Table 1, the studious description is provided. It corresponds to the research purpose that is to know pre-service mathematics teachers' understanding of the concept.

Table 1

The indicator of concept understanding

\begin{tabular}{|c|c|c|}
\hline Indicator & Description & Students' ability \\
\hline $\begin{array}{l}\text { Individual } \\
\text { concept }\end{array}$ & $\begin{array}{l}\text { 1. Understanding the definition of the } \\
\text { concept. }\end{array}$ & $\begin{array}{l}\text { 1. Explaining the concept of Probability based } \\
\text { on what they comprehend. }\end{array}$ \\
\hline & $\begin{array}{l}\text { 2. Determining example and non- } \\
\text { example. } \\
\text { 3. Understanding } \\
\text { representations such as table, } \\
\text { diagram, symbol, and numeral. }\end{array}$ & $\begin{array}{l}\text { 2. Determining example and non-example of } \\
\text { Probability. } \\
\text { 3. Apprehending a representation such as } \\
\text { table, diagram, symbol, and numeral. }\end{array}$ \\
\hline $\begin{array}{l}\text { Connecting } \\
\text { some } \\
\text { concepts }\end{array}$ & $\begin{array}{l}\text { Connecting between one concept and } \\
\text { other concepts. }\end{array}$ & $\begin{array}{l}\text { Implementing the connection between concept } \\
\text { and procedure. }\end{array}$ \\
\hline
\end{tabular}


Table 1 (Continued)

\begin{tabular}{llllll}
\hline \multicolumn{1}{c}{ Indicator } & \multicolumn{1}{c}{ Description } & \multicolumn{1}{c}{ Students' ability } \\
\hline $\begin{array}{l}\text { Connecting } \\
\text { concept to }\end{array}$ & 1. & $\begin{array}{l}\text { Defining a concept based on its } \\
\text { operation. }\end{array}$ & 1. & $\begin{array}{l}\text { Defining the concept of Probability based on } \\
\text { its operation. }\end{array}$ \\
$\begin{array}{l}\text { its } \\
\text { operation }\end{array}$ & 2. $\begin{array}{l}\text { Through the operation, the } \\
\text { conceptual understanding can be } \\
\text { advanced to higher standard. }\end{array}$ & 2. Developing concept having learned. \\
\hline
\end{tabular}

\section{Results and Discussion}

The result of the written test and interview for the three subjects regarding the understanding concept ability as one of the teacher's professional competencies are presented as follows.

\section{Subject with advanced mathematics ability}

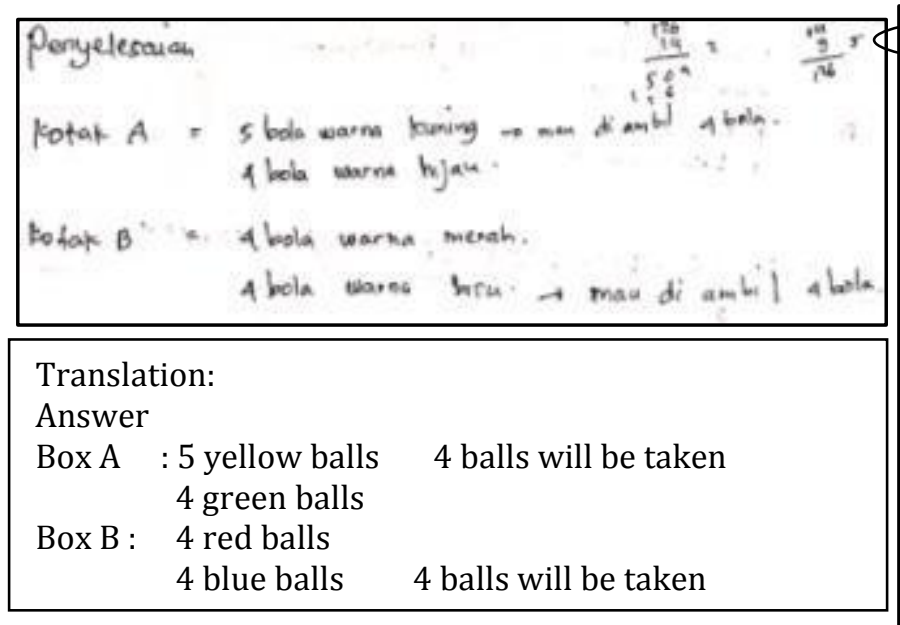

Translation:

Answer

4 green balls

4 blue balls

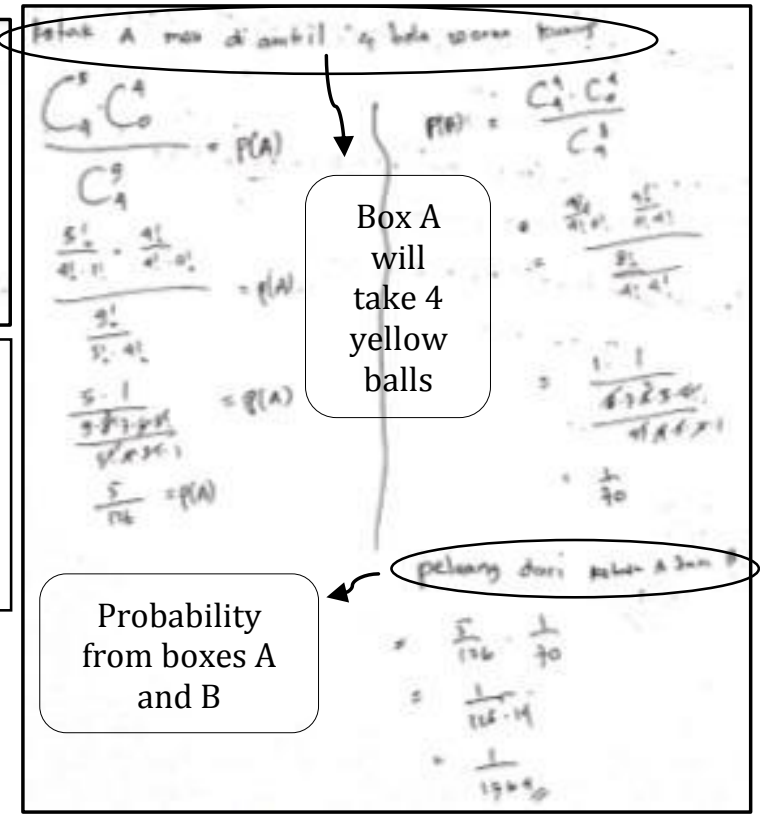

Figure 1. The written test result of subject with advanced mathematics ability

Figure 1 is the answer sheet of the written test results of subjects with advanced mathematicsability regarding concept understanding of the probability lessons, especially on combination content. Based on the written test result in Figure 1, subject with advanced mathematics ability (ST) could do the written test of probability lessons correctly. Moreover, he was able to name a commensurate strategy to finish it. The excerpt of the interview between the researcher (R) and ST is presented as follows.

$R \quad$ : When did you read this question, what methods or strategies were used to solve it?

ST : Looking for probability from each removal in each box which is in box A and box B. In this case, it happens that in box $A$ and box $B$ the balls are in different colors and what you want to take has been determined. Fox $A$ is specialized to take 4 yellow balls while box $B$ is specialized to take 4 blue balls so I looked for the probability from each box; how many are the probabilities in box $A$ and box $B$ because box A consists of two balls in different colors, these are yellow and green. Therefore, there was a possibility that when you would take it, you did not get the requested color right away. So, In my opinion, because the four balls must be yellow, then we have a chance to get 5 color balls. Those have to be taken four so it must use a combination. 
Based on the interview result, ST could choose an appropriate strategy to answer, searching the number of the probability of the occurrence regarding 4 yellow balls removal from box A and 4 blue balls from box B by using combination concept. ST could also comprehend the reason why he utilized the combination concept in answering the question. He had been able to determine example and non example from the concept used. However, he had not been able as yet to present any reasons concerning the general use of the combination concept. When he was asked further why not employing another formula such as using permutation concept, ST could not correct answers since he had not apprehended the concept completely. It is discussed in the following interview result:
$R \quad$ : Why did you have to use a combination?
ST : Because in the question there are many ways of taking the balls so when we were about to take, we are unlikely to get the same ball. So, from the five balls, for example, all of them are yellow, but we never know if the ball we get the first is yellow, whether the second is also yellow or not, for example there are 1,2,3,4,5, we do not know if what we took first is 1,2,3,4,5 or 2,3,4,5,1 and so on.
$R \quad$ : Why did you not use a permutation or something?
ST : Because, after taking the ball, it was still returned. It means, it is not allowed except in the matter of taking the ball without being returned, it is different from the track that combination may be repeated for example 1,2,3,4. the second take can be 3,2,4,1 and so on

Besides determining an appropriate strategy, ST could also connect one concept to other concepts, after having determined the number of event and determining sample space by using the combination. He continued using probability concept towards each box to seek the probability of 4 yellow balls removal from box A and the probability of 4 blue balls removal from box B at the same time. It is described in the following interview result.

ST : So, we looked for box A first, we looked for probability from box A, so (combination of 4 of 5), the green color was not taken at all (combination 0 of 4), then for $n(S)$ there were many possibilities how to take it want to take 4 pairs of green with yellow or all green or all yellow (combination of 4 of 9 )

$R \quad$ : What is $C$ (combination of 4 of 9 ) looking for?

ST : To find $n(S)$

$S T$ : This is the formula for the combination, for example $C_{n}^{m}$ (a combination of $n$ from $m$ ), then the formula is $\frac{m !}{n !(m-n) !}$ So $n$ here is 4 and $m$ is 5 . We can write $\frac{5 !}{4 !(5-4) !}=\frac{5.4 !}{4 !}=5$. And all the ways like that so you get the odds of box A are 5/6 to take 4 yellow balls

$R \quad:$ And then?

ST : Looking for probability from box B, from box $B$ we want to take 4 blue balls, so it's the same as before, the four are blue balls so the red ones are not taken so $C_{4}^{5}$ (combination of 4 of 5) and $C_{0}^{4}$ (combination 0 of 4 ) for $N(S) C_{4}^{8}$ (a combination of 4 of 8 ).

$R \quad$ : Why should (combination of 4 of 8 )

ST : Because in the problem there are 4 red balls and 4 blue balls, so for the sample space we can

take 1 blue ball or 1 red ball and other colour for $N(S)$, so

$$
P(A)=\frac{n(A)}{n(S)}
$$

After simplifying the question, it is obtained $1 / 70$ so the odds are from box $A$ and box $B$ just multiplied by the odds from each box $A$ and box $B$

$R \quad$ : Why did you have to multiply?

ST : Because we want to take the ball from box $A$ and box $B$, so we look for probability from box $A$ and box B. It could be that from box $A$ when we take it we have the probability to take one ball, it turns out that the other one is not

$R \quad$ : Why is it multiplied why not added or divided or subtracted? 
ST : For example, if added, it means that taking is not simultaneous, so we must take it one by one, meaning that $A$ has to finish first, $B$ continues to finish first, so it does not coincide, here is the word "and" so simultaneously, so take it simultaneously, in box A too Approximately how many chances were taken and in Box $B$ about how many probability were taken according to my understanding

However, at the end of answering the question, ST could not wholly explain the excuse why seeking the probability of ball removal from box A and box B, why it should be multiplication, and why it did not use other operations such as addition, subtraction, or division. Therefore, even though the answer given was correct and asked further questions regarding the probability category he answered belongs, he could not answer. Furthermore, the last concept understanding is connecting symbol with a concept. ST had been able to answer accurately. It is described in the following interview result.

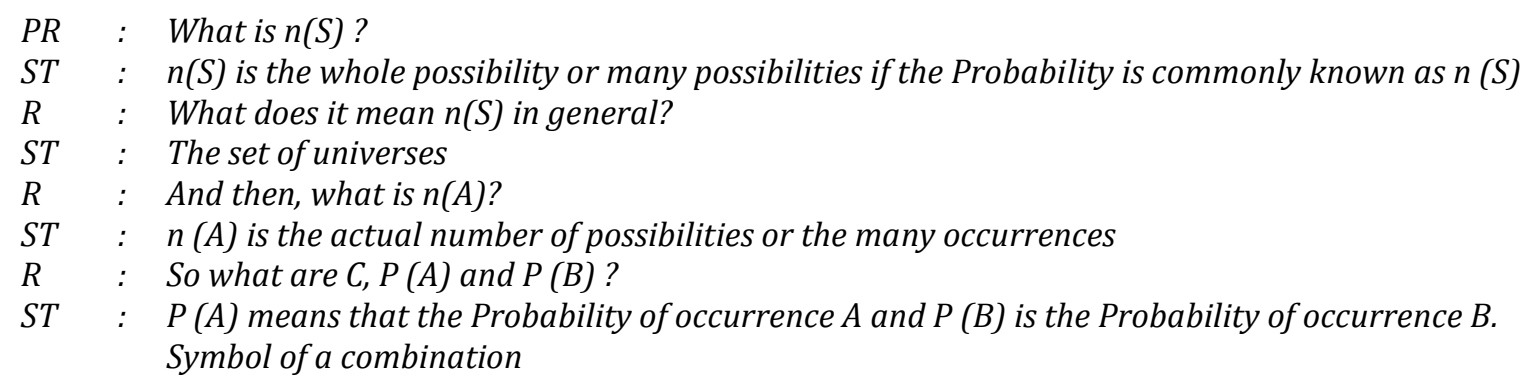

In a thorough going interview with ST regarding the definition of the concept, ST did not comprehend its definition itself. He states that the concept he employed in answering the question is only a combination concept because probability is not a concept, but it is a theory. According to ST, a concept is a technique or a complete strategy to solve a problem. The excerpt of the interview is presented below:

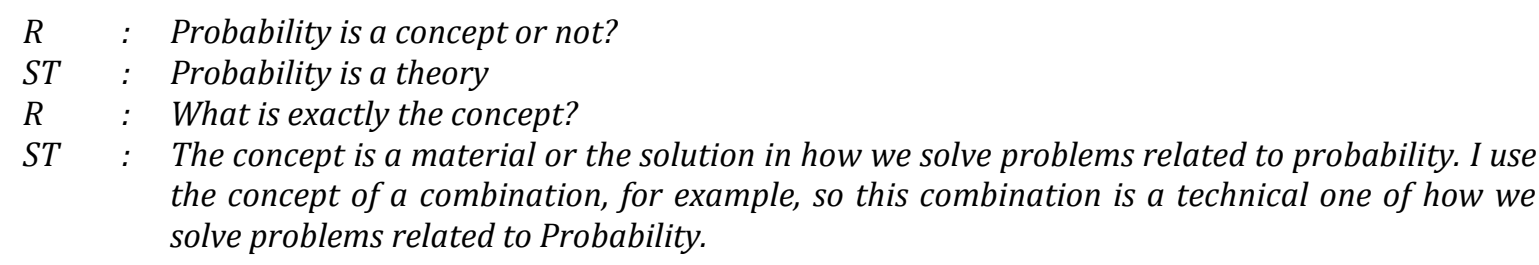

\section{Subject with intermediate mathematics ability}

Figure 2 is the answer sheet for the written test results of subjects with intermediate mathematical ability regarding concept understanding of the probability material, especially on combination content. Based on the written test result in Figure 2, subject with intermediate mathematics ability (SS) could not do the written test of probability lessons correctly. Based on the interview result with the subject, however, he was able to name an appropriate strategy to finish the question. It is discussed as the following interview result.

\footnotetext{
$R \quad$ : What strategies or methods did you use in solving this problem?

SS : Combination

$R \quad$ : Why did you use that method or strategy?

SS : Because there are 5 yellow balls and 4 green balls here, the balls will be unified so 9 will be mixed. There are 5 yellow balls here. Meanwhile, the question is box A to take 4 yellow balls. Looking for probability, A's chances are taking 4 yellow balls from box $A$ and 4 blue balls from box B. Looking for probability, namely the chances of being taken for the sum of all the balls because here there are 5 yellow balls that you want to take, only 4 yellow balls, so the way to take 5 yellow balls is if I take 4 yellow balls, I use a combination
} 
However, when asked further questions concerning why he employed combination in finishing the question, he could not give any correct answer. He did not understand why the combination was used. Finally, he stated that he utilized combination due to random removal as presented in the excerpt of the interview as follows.

$R \quad$ : Why did you use a combination method? why not use another way?

SS : I don't know the other way, I just remember the combination, and I only know the combination, and the ball is randomly drawn

$R \quad$ : So if the random collection uses a combination and if it is not random using a permutation, is it right?

SS : Yes, because the ball is randomly drawn. The combination is the chance of taking it randomly. So, if all the colors are the same, it will still be mixed except the 4 balls that must be taken from the 4 new balls are not random and all taken.

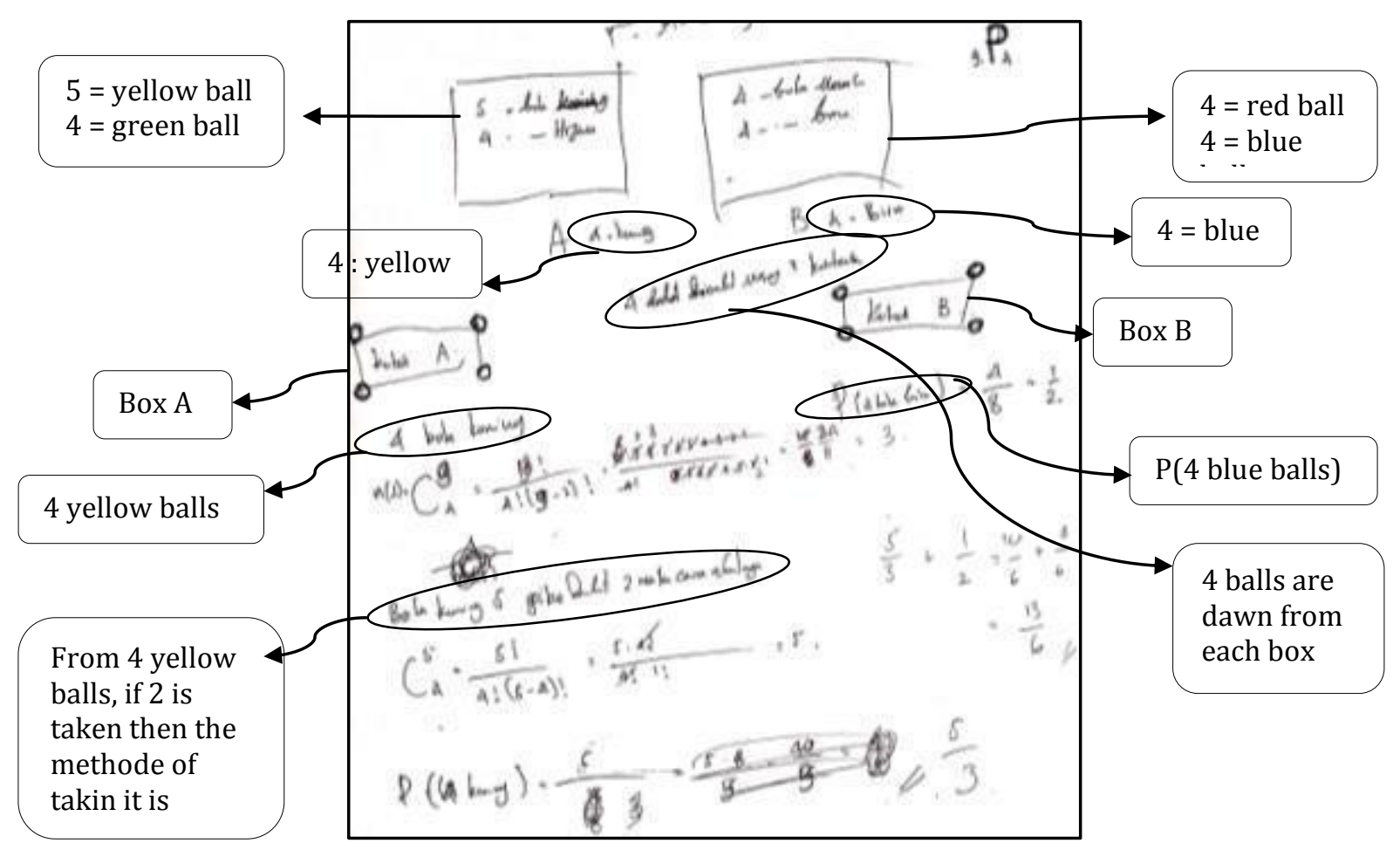

Figure 2. The written test result of subject with intermediate mathematics ability

However, when asked further questions concerning why he employed combination in finishing the question, he could not give any correct answer. He did not understand why the combination was used. Finally, he stated that he utilized combination due to random removal, as what is quoted from the interview below:

$R \quad$ : Why did you use a combination method? why not use another way?

SS : I don't know the other way, I just remember the combination, and I only know the combination, and the ball is randomly drawn

$R \quad$ : So if the random collection uses a combination and if it is not random using a permutation, is it right?

SS : Yes, because the ball is randomly drawn. The combination is the chance of taking it randomly. So, if all the colors are the same, it will still be mixed except the 4 balls that must be taken from the 4 new balls are not random and all taken. 
SS's incomprehension towards combination concept induces him false in determining probability towards box B. He did not use combination in determining either sample point or sample space to decide the probability of 4 blue balls in box B since the available balls in box $B$ are 4 blue balls and 4 red balls. As a result, the number of balls which will be taken out equals to the number of available balls. Therefore, he perceived that balls which are going to be taken are 4 desired blue balls. It is discussed as the following interview.

$R \quad$ : You only explain about taking the ball in box $A$, then what about taking the ball in box $B$ ?

SS : In the problem, you are instructed to take 4 blue balls, while in box B there are 4 blue balls, so I don't need to look for the combination anymore because the number is the same

$R \quad: \quad$ So just take 4 balls, right?

SS : Here there are 4 blue balls. In the question, I was instructed to take 4 blue balls so I don't need to look for ways of taking like in box A again because 4 blue balls will already be taken. There will be no blue balls left in the box, so all blue balls will be taken all

$R \quad:$ So, you don't need to look for that combination?

SS : Yes, idon't

Besides the lack of comprehension of combination concept, he also lacked the understanding of probability concept. He could not able to comprehend probability definition. He was a bit short of apprehending either sample point or sample space in probability even though he understood the procedure of doing probability and had been able to do combined with a correct procedure as presented in the excerpt of the following interview.

SS : These 5 are not specific, while the 4 balls to be taken are yellow. Here there is a requirement for 4 yellow out of 5 so I use this combination $C_{4}^{5}$

$R \quad$ : Why do you have to use Probability $C_{4}^{5}$ (a combination of 4 of 5)?

SS : Because 5 ways are obtained from (a combination of 4 of 5), namely the specific collection of 4 yellow balls from 5 yellow balls

$R \quad:$ According to your understanding what is probability? Here you write the odds of taking 4 yellow balls as $\frac{5}{8}$. What is 5 , what is 8 , and what is actually 8 , why the position is like that, why don't you just turn around

SS : 5 is the way he took it from the 4 yellow balls

At the end of answering the question, SS could not also seek the probability of 4 yellow balls removal from box $\mathrm{A}$ and 4 blue balls removal from box B. He added the outcome of probability removal in box $\mathrm{A}$ and box $\mathrm{B}$ and he also did not know why he used addition, and he was not able to determine to what category the probability that he answered belongs. It is discussed in the following interview.

$R \quad: \quad$ The question in the question is what is the chance of taking 4 yellow balls from box $A$ and the chances of taking 4 blue balls from box $B$

SS : the results are Summed, $\frac{5}{3}+\frac{1}{2}=\frac{10}{6}+\frac{3}{6}=\frac{13}{6}$

$R \quad$ : So the odds of box A and box B are $\frac{13}{6}$ ?

SS : Yes

Furthermore, the previous concept understanding is connecting symbol with a concept. SS had been able to answer correctly as presented in the excerpt of the interview as follows.

$R \quad:$ What $C$ and P mean?

SS : $\quad$ C is the symbol of combination, $P$ is the symbol of Probability 


\section{Subject with basic mathematics ability}

Figure 3 is the answer sheet for the written test results of subjects with basic mathematical ability regarding concept understanding of the probability material, especially on combination content. Based on the written test result in Figure 3, the subject with basic mathematics ability (SR) could not do the written test of probability lessons accurately. SR could name an appropriate completion strategy to answer it, that is seeking combination to determine the sample point and the sample space of the probability of the ball removal from the box. However, it is arguable that he only memorized the procedure without comprehending what he was answering. SR himself was not able to clarify the result of his answer. He did not apprehend what combination is and how it is used. In addition, he could not determine the example and the non-example of combination concept itself, as discussed in the following interview:

SR : Because here there are two boxes, namely box $A$ and box B, box $A$ contains 5 yellow balls and 4 green balls and for box $B$ contains 4 red balls and 4 yellow balls. The question is the chances of taking 4 yellow balls from box $A$ and 4 blue balls from box $B$, so I focused on taking 4 yellow balls from box $A$ and 4 blue balls from box $B$
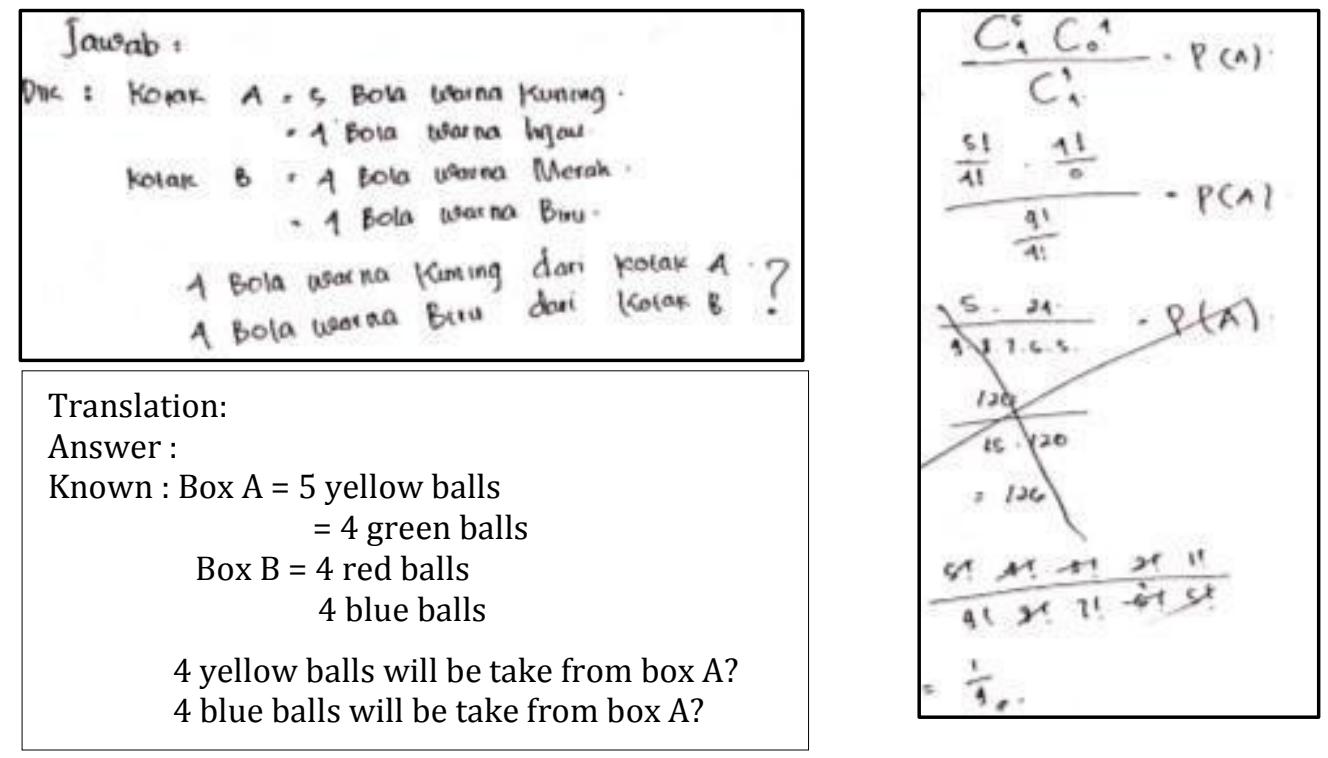

Figure 3. The written test result of subject with basic mathematics ability

Besides the incomprehensibility of concept definition used, the procedure employed in answering the question was also incorrect, like the use of combination procedure, factorial, and probability. He was not able to understand what he was writing. It is discussed in the interview as follows.

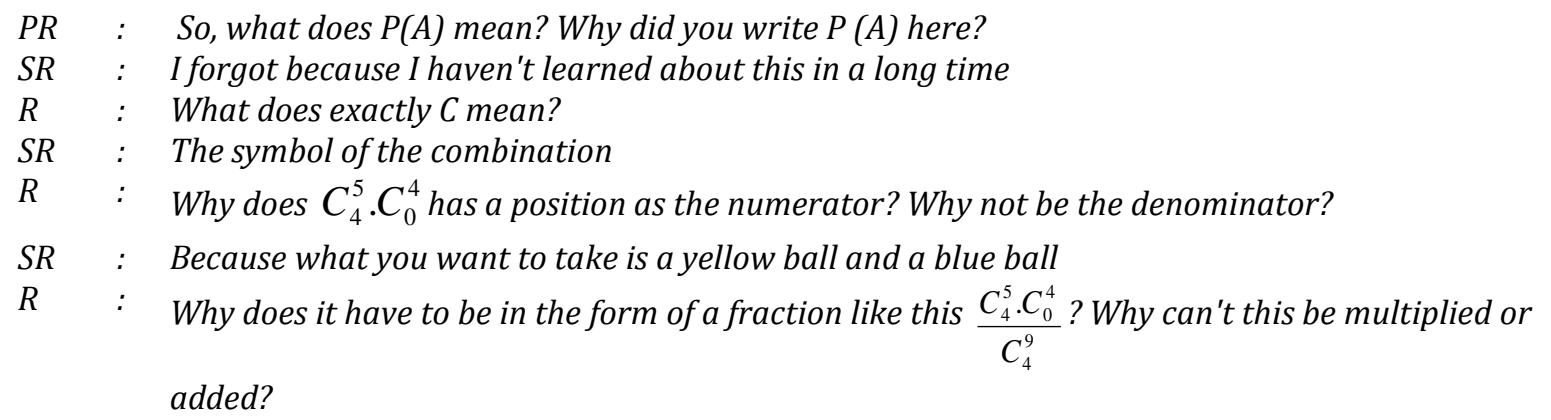




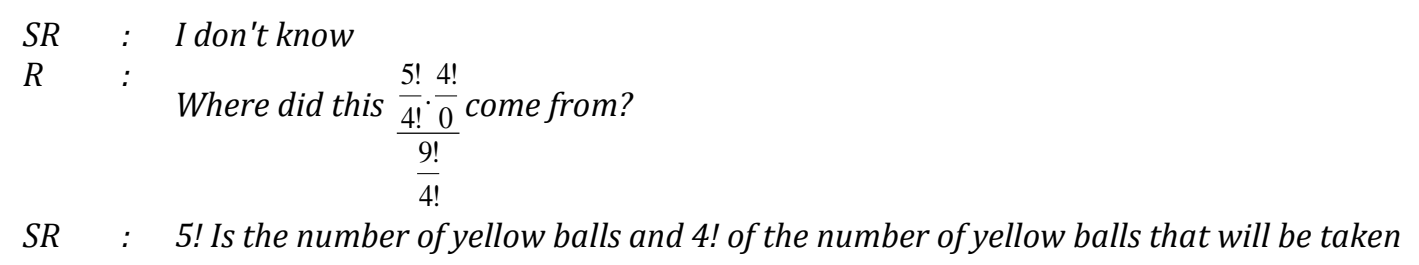

Furthermore, for the last concept, understanding concept and its symbol, SR indicates could not correlate them. He did not understand the meaning of $\mathrm{P}(\mathrm{A})$ which he wrote because he could not answer correctly when He asked about it. He did not know and forgot about what he was writing. The excerpt of the interview with SR is presented below.

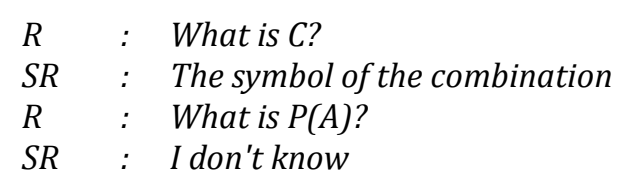

\section{The ability of concept understanding viewed based on mathematics ability}

Based on the analysis result of the three research results towards the subjects, it is grouped as presented in Table 2 .

Table 2

The Difference of Concept Understanding Viewed Based on Mathematics Ability

\begin{tabular}{|c|c|c|c|}
\hline Indicator & $\begin{array}{l}\text { Subject with Advanced } \\
\text { Mathematics Ability }\end{array}$ & $\begin{array}{l}\text { Subject with Intermediate } \\
\text { Mathematics Ability }\end{array}$ & $\begin{array}{l}\text { Subject with Basic } \\
\text { Mathematics Ability }\end{array}$ \\
\hline $\begin{array}{l}\text { Individual } \\
\text { Concept }\end{array}$ & $\begin{array}{l}\text { - Based on this indicator, the } \\
\text { subject has not been able to } \\
\text { understand the definition of } \\
\text { concept. However, he has } \\
\text { been able to explain } \\
\text { correctly concerning the use } \\
\text { of the concept he employed } \\
\text { in answering the question. } \\
\text { He could give the example } \\
\text { and the non-example of the } \\
\text { concept such as in } \\
\text { determining the use of } \\
\text { combination and seeking } \\
\text { Probability of an event. } \\
\text { - The subject has been able to } \\
\text { employ the correct } \\
\text { procedure of every } \\
\text { completion step, such as the } \\
\text { use of pattern, symbol, and } \\
\text { numeral like factorial } \\
\text { numbers, combination } \\
\text { procedure, and the } \\
\text { procedure of answering } \\
\text { probability. a }\end{array}$ & $\begin{array}{l}\text { - Based on this indicator, } \\
\text { the subject has not been } \\
\text { able to comprehend the } \\
\text { definition of concept and } \\
\text { explain the concept he } \\
\text { used in answering the } \\
\text { question, for instance, he } \\
\text { has not understood the } \\
\text { reason of the used } \\
\text { combination concept and } \\
\text { to determine Probability } \\
\text { of the ball removal in } 2 \\
\text { boxes so that it caused an } \\
\text { error in determining } \\
\text { probability of the ball } \\
\text { removal in the second box. } \\
\text { - The subject has been able } \\
\text { to employ the correct } \\
\text { procedure of every } \\
\text { completion step, such as } \\
\text { the use of pattern, symbol, } \\
\text { and numeral like factorial } \\
\text { numbers, combination } \\
\text { procedure, and the } \\
\text { procedure of answering } \\
\text { probability. }\end{array}$ & $\begin{array}{l}\text { - Based on this indicator, } \\
\text { the subject was not able } \\
\text { to comprehend the } \\
\text { definition of concept and } \\
\text { the concept he used in } \\
\text { answering the question. } \\
\text { - The subject was not able } \\
\text { to employ the correct } \\
\text { procedure of every } \\
\text { completion step, such as } \\
\text { the use of pattern, } \\
\text { symbol, and numeral like } \\
\text { factorial numbers, } \\
\text { combination procedure, } \\
\text { and the procedure of } \\
\text { answering probability. }\end{array}$ \\
\hline
\end{tabular}


Table 2 (Continued)

\begin{tabular}{|c|c|c|c|}
\hline Indicator & $\begin{array}{c}\text { Subject with Advanced } \\
\text { Mathematics Ability }\end{array}$ & $\begin{array}{c}\text { Subject with Intermediate } \\
\text { Mathematics Ability }\end{array}$ & $\begin{array}{c}\text { Subject with Basic } \\
\text { Mathematics Ability }\end{array}$ \\
\hline $\begin{array}{l}\text { Connecting } \\
\text { some } \\
\text { concepts }\end{array}$ & $\begin{array}{l}\text { The subject has been able to } \\
\text { connect one concept to other } \\
\text { concepts. He was able to } \\
\text { determine the finishing } \\
\text { strategy correctly so that the } \\
\text { solution of the answer he did } \\
\text { was also correct even though } \\
\text { he did not comprehend what } \\
\text { concept he employed in the } \\
\text { last completion. }\end{array}$ & $\begin{array}{l}\text { The subject was lack of } \\
\text { ability to connect some } \\
\text { concepts. Even though he } \\
\text { employed the accurate } \\
\text { strategy, in the last } \\
\text { completion, he lacked the } \\
\text { understanding of connecting } \\
\text { one concept to other } \\
\text { concepts so that it caused an } \\
\text { error in determining the } \\
\text { solution of the completion. }\end{array}$ & $\begin{array}{l}\text { The subject was not able to } \\
\text { connect some concepts. } \\
\text { The strategy he used was } \\
\text { not accurate so that it } \\
\text { caused an error in } \\
\text { determining the solution of } \\
\text { the completion. }\end{array}$ \\
\hline $\begin{array}{l}\text { Connecting } \\
\text { concept } \\
\text { with its } \\
\text { operation }\end{array}$ & $\begin{array}{l}\text { - The subject has been able to } \\
\text { connect a concept with its } \\
\text { operation, for instance P(A); } \\
\text { the Probability of event A, } \\
\mathrm{n}(\mathrm{A}) \text {; the number of events } \\
\text { in A, n(S); the sample space } \\
\text { of an event and } C_{4}^{5} \text { (the } \\
\text { combination of } 4 \text { of } 5) \text {. } \\
\text { - The subject had not been } \\
\text { able to enhance concept } \\
\text { understanding since he had } \\
\text { not understood concepts } \\
\text { well, particularly the } \\
\text { probability concept. }\end{array}$ & $\begin{array}{l}\text { - The subject has been able } \\
\text { to connect concept with its } \\
\text { operation, for instance } \\
\text { P(A); the Probability of } \\
\text { event } \mathrm{A}, \mathrm{n}(\mathrm{A}) \text {; the number } \\
\text { of events in } \mathrm{A}, \mathrm{n}(\mathrm{S}) \text {; the } \\
\text { sample space of an event } \\
\text { and } C_{4}^{5} \text { (the combination } \\
\text { of } 4 \text { of } 5) \text {. } \\
\text { - The subject had not been } \\
\text { able to enhance concept } \\
\text { understanding since he } \\
\text { had not comprehended } \\
\text { the concept well, } \\
\text { particularly } \\
\text { probability concept. }\end{array}$ & $\begin{array}{l}\text { - The subject was not able } \\
\text { to connect a concept } \\
\text { with its operation, when } \\
\text { asked the meaning of } \\
\text { P(A) he wrote. He was } \\
\text { not able to answer } \\
\text { correctly. He answered } \\
\text { that he did not know and } \\
\text { he forgot what he was } \\
\text { writing. } \\
\text { - The subject had not been } \\
\text { able to enhance concept } \\
\text { understanding he had } \\
\text { since had not been able } \\
\text { to understand concept } \\
\text { well, particularly } \\
\text { Probability concept. }\end{array}$ \\
\hline
\end{tabular}

Concept understanding ability is an ability which is imperative to be possessed especially by pre-service teachers who will enter into the education sphere. It is also a professional competency that should be resided in teachers. Teachers knowledge and competency of mathematics have a crucial role towards teaching practice (Stahnke, Schueler, \& Winter, 2016). A teacher's good competence will influence teaching and learning process in a class as a good instruction conducted by teachers to students induces the lesson delivered easier to be comprehended by students (Priskila \& Helti Lygia, 2019). Thus, the component mastery of content knowledge and teachers' mathematical pedagogy is more essential than other components (Qian \& Youngs, 2015). In the research result, the concept understanding ability of the three subjects, the subject with advanced, intermediate, and basic mathematics ability has been analyzed.

The subject with advanced mathematics ability could employ the concept and the correct procedure of every completion step and connect one concept to other concepts. The solution of the answer he did was also correct, and he could also connect a concept with its operation. Subject with intermediate mathematics ability could employ the concept correctly and the procedure of every completion step. However, he could not connect one concept with other concepts so that it caused an error to determine the solution of the answer. Meanwhile, he had also been able to connect a concept with its operation. Subject with basic mathematics ability could not correctly employ the concept and the procedure of every completion step and he was also not able to connect some concepts so that it 
caused an error in determining the solution of the answer. In addition to that, he was not able to connect a concept to its operation. Meanwhile, concerning the indicator of concept understanding improvement, the three subjects have not reached this phase since they have not understood the definition of concept correctly, particularly probability concept, even though the subject with advanced mathematics ability is procedurally capitalized.

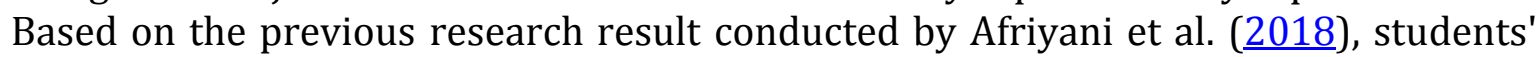
concept understanding ability is grouped into three stages. First, students' can perform one-concept interpretation, but they cannot perform a correct completion since they only employ one concept in creating a conclusion. Second, they can perform interpretation by employing some concepts, but they enable an error in determining the completion because information synthesis or interim conclusion was not executed. Third, they can perform the interpretation of some concepts in completion and provide a correct conclusion based on a completion process. Based on the previous research by Hutauruk and Panjaitan (2020), pre-service teachers lacked competence in mastering mathematics learned at school, especially in understanding the concept. The difference in research result level can occur due to factors such as more extensive area, the research field, purpose, and focus of the research conducted (Chick, 1998).

Should it be viewed from the previous discussion, the competency of teacher candidates needs to be explicitly advanced concept understanding towards probability lessons. There are five strategies can enhance concept understanding ability that can be implemented either at school or college. First, the strategy selects learning strategy and considering the number of learning hours since they can impact learning effectiveness (Tsubaki, Ogawara, \& Tanaka, 2020). Second, it provides scaffolding by entering into dialogue with students. It can also enhance students' conceptual understanding (Kazak, Wegerif, \& Fujita, 2015). Third, it administers assignments or exercises repeatedly since students can also broaden their knowledge based on their previous experience (Kazak \& Confrey, 2007). Fourth, it gives the first stimulus by apprising the philosophy and the history of mathematical theory, specifically probability in order that students' motivation improves learning the material (Kuznetsova, 2019). Fifth, it conducts cognitive guidance analysis, concept clarification, logical multiplication and student ratio(Nunes, Bryant, Evans, Gottardis, \& Terlektsi, 2014). To enhance teachers' professionalism, however, teachers should employ an intuitive approach followed by a subjective approach, frequency, and classic (Vásquez \& Alsina, 2019).

\section{Conclusion}

Based on the research result and the previous discussion, it is obtained a conclusion that the pre-service teachers' concept understanding ability remains varied based on their ability level of mathematics. The subject with advanced mathematics ability could employ the concept and the correct procedure of every completion step and connect one concept to other concepts so that the solution of the answer he did was correct. Furthermore, he could connect concept with its operation. The subject with intermediate mathematics ability could employ the concept correctly and the procedure of every completion step. However, he could not connect one concept to other concepts to induce an error in determining the solution of the answer. The subject had been able to connect a concept with its operation. The subject with basic mathematics ability could not employ a concept and a procedure accurately towards every completion step and not able to connect some concepts, so that it induced an error in determining the solution the answer. The subject could not also be able 
to connect a concept with its operation. Concerning the indicator of concept understanding advancement, the three subjects have not reached this phase. They had not been able to comprehend the definition of concept fabulously specifically probability concept, even though the subjects with mathematics ability are procedurally capital.

Hopefully, this research result will be a reference for the subsequent researchers in order that it becomes more enhanced or the research subject is more widened and either for high school students or higher education students. Thus, it can either improve the concept understanding ability they have possessed or enrich the students' concept understanding.

\section{Acknowledgment}

The researchers would like to thank all those who have contributed to this research, especially the lecturers who are willing to guide and their fellow students willing to be the subject.

\section{Bibliography}

Abrahamson, D. (2014). Rethinking Probability Education: Perceptual Judgment as Epistemic Resource. In E. J. Chernoff \& B. Sriraman (Eds.), Probabilistic Thinking, Advances in Mathematics Education (pp. 239-260). https://doi.org/10.1007/978-94007-7155-0 13

Afriyani, D., Sa'dijah, C., Subanji, S., \& Muksar, M. (2018). Characteristics of Students' Mathematical Understanding in Solving Multiple Representation Task based on Solo Taxonomy. International Electronic Journal of Mathematics Education, 13(3), 281287. https://doi.org/10.12973/iejme/3920

Batanero, C. (2020). Probability Teaching and Learning. In S. Lerman (Ed.), Encyclopedia of Mathematics Education (Second Edi, pp. 682-686). https://doi.org/10.1007/978-94007-4978-8 47

Batanero, C., Contreras, J. M., Díaz, C., \& Sánchez, E. (2015). Prospective teachers' semiotic conflicts in computing probabilities from a two-way table. International Electronic Journal of Mathematics Education, 10(1), 3-16. https://doi.org/10.12973/mathedu.2015.101a

Brase, G. L., Martinie, S., \& Castillo-Garsow, C. (2014). Intuitive Conceptions of Probability and the Development of Basic Math Skills. In E. J. Chernoff \& B. Sriraman (Eds.), Probabilistic Thinking, Advances in Mathematics Education (pp. 161-194). https://doi.org/10.1007/978-94-007-7155-0 10

Chick, H. (1998). Cognition in the formal modes: Research mathematics and the SOLO taxonomy. Mathematics Education Research Journal, 10(2), 4-26. https://doi.org/10.1007/BF03217340

Elbehary, S. G. A. (2020). Providing Insights into the Intended Curriculum of Probability for Basic Education Sector in Egypt from a Comparative Perspective. International Electronic Journal of Mathematics Education, 15(2), 1-16. https://doi.org/10.29333/iejme/7603

Estrada, A., \& Batanero, C. (2020). Prospective Primary School Teachers' Attitudes towards Probability and its Teaching. International Electronic Journal of Mathematics Education, 15(1), 1-14. https://doi.org/10.29333/iejme/5941

Faradillah, A. (2018). Keterkaitan Pencapaian Nilai Akhir Dengan Pemahaman Konsep Matematis Mahasiswa Calon Guru. Majamath, 1(1), 16-23. 
https://doi.org/10.36815/majamath.v1i1.117

Groth, R. E. (2010). Teachers' construction of learning environments for conditional probability and independence. International Electronic Journal of Mathematics Education, 5(1), 32-55.

Hutauruk, A. J., \& Panjaitan, S. M. (2020). Penguasaan materi matematika sekolah dan permasalahannya pada mahasiswa prodi pendidikan matematika. Jurnal $\begin{array}{llll}\text { Pembelajaran Matematika } & \text { Inovatif, }\end{array}$ https://doi.org/10.22460/jpmi.v3i1.p81-90

Indriani, A. (2020). Investigasi Kesalahan Mahasiswa dalam Menyelesaikan Soal Cerita Materi Peluang. Jurnal Pendidikan Matematika, 3(2), 158. https://doi.org/10.21043/jmtk.v3i2.7174

Ihsan, I. R., \& Kosasih, U. (2018). Penelitian Pendahuluan Mengenai Desain Pembelajaran Terkait Berpikir Kombinatorial. Seminar Nasional Pendidikan Matematika Universitas Suryakancana (MINATKU), 131-136. https://doi.org/https://doi.org/10.31227/osf.io/43vc8

Jin, H., \& Wong, K. Y. (2015). Mapping Conceptual Understanding of Algebraic Concepts: an Exploratory Investigation Involving Grade 8 Chinese Students. International Journal of Science and Mathematics Education, 13(1), 683-703. https://doi.org/10.1007/s10763-013-9500-2

Kazak, S., \& Confrey, J. (2007). Elementary school students' intuitive conceptions of random distribution. International Electronic Journal of Mathematics Education, 2(3), 227244.

Kazak, S., Wegerif, R., \& Fujita, T. (2015). Combining scaffolding for content and scaffolding for dialogue to support conceptual breakthroughs in understanding probability. ZDM - Mathematics Education, 47(7), 1269-1283. https://doi.org/10.1007/s11858-015$\underline{0720-5}$

Kuznetsova, E. (2019). Probabilistic Ideas and Methods in Undergraduate Mathematics: Axiological Aspects. International Electronic Journal of Mathematics Education, 14(2), 363-373. https://doi.org/10.29333/iejme/5720

NCTM. (2000). Answer To Frequently Asked Questions About Principles And Standards For School Mathematics. In Principles and Standards for School Mathematics (pp. 1-4). Reston, VA.

Nilsson, P. (2014). Experimentation in Probability Teaching and Learning. In E. J. Chernoff \& B. Sriraman (Eds.), Probabilistic Thinking, Advances in Mathematics Education (pp. 509-532). https://doi.org/10.1007/978-94-007-7155-0 27

Nunes, T., Bryant, P., Evans, D., Gottardis, L., \& Terlektsi, M. E. (2014). The cognitive demands of understanding the sample space. ZDM - International Journal on Mathematics Education, 46(3), 437-448. https://doi.org/10.1007/s11858-014-0581$\underline{3}$

OECD. (2016). "PISA 2015 Mathematics Framework", in PISA 2015 Assessment and Analytical Framework: Science, Reading, Mathematic and Financial Literacy. Paris: OECD Publishing.

Priskila, Y., \& Helti Lygia, M. (2019). Tinjauan Pedagogical Content Knowledge Guru Pada Materi Peluang. Jurnal Pendidikan Matematika, 3(1), 104-115. https://doi.org/https://doi.org/10.31004/cendekia.v3i1.85

Putridayani, I. B., \& Chotimah, S. (2020). Analisis Kesulitan Belajar Siswa Dalam Pelajaran Matematika Pada Materi Peluang. MAJU, 7(1), 57-62. 
Qian, H., \& Youngs, P. (2015). The effect of teacher education programs on future elementary mathematics teachers ' knowledge : a five- country analysis using TEDS-M data. Journal of Mathematics Teacher Education. https://doi.org/10.1007/s10857014-9297-0

Sánchez, E., \& Landín, P. R. (2014). Levels of Probabilistic Reasoning of High School Students About Binomial Problems. In Probabilistic Thinking, Advances in Mathematics Education (pp. 581-597). https://doi.org/10.1007/978-94-007-7155$\underline{031}$

Savard, A. (2014). Developing Probabilistic Thinking: What About People's Conceptions? In E. J. Chernoff \& B. Sriraman (Eds.), Probabilistic Thinking, Advances in Mathematics Education (pp. 283-298). https://doi.org/10.1007/978-94-007-7155-0 15

Stahnke, R., Schueler, S., \& Winter, B. R. (2016). Teachers ' perception , interpretation , and decision - making : a systematic review of empirical mathematics education research. ZDM. https://doi.org/10.1007/s11858-016-0775-y

Sundary, P., Jatmiko, A., \& Widyastuti, R. (2020). Metaphorical Thinking Approach With Google Classroom: Its Effect Towards Students ' Understanding of Mathematical Concept Skills. Indonesian Journal of Science and Mathematics Education, 3(1), 37-47. https://doi.org/10.24042/ijsme.v3i1.5900

Tsubaki, M., Ogawara, W., \& Tanaka, K. (2020). An Analysis for the Qualitative Improvement of Education and Learning based on the Way of Learner Errors in Descriptive Questions. International Electronic Journal of Mathematics Education, 15(3), 1-27. https://doi.org/10.29333/iejme/7840

Vásquez, C., \& Alsina, Á. (2019). Observing Mathematics Teaching Practices to Promote Professional Development: An Analysis of Approaches to Probability. International Electronic Journal of Mathematics Education, 14(3), 719-733. https://doi.org/10.29333/iejme/5866

Williams, A., \& Nisbet, S. (2014). Primary School Students' Attitudes To and Beliefs About Probability. In E. J. Chernoff \& B. Sriraman (Eds.), Probabilistic Thinking, Advances in Mathematics Education (pp. 683-708). https://doi.org/10.1007/978-94-007-7155$\underline{036}$

Yilmaz, R. (2020). Prospective Mathematics Teachers' Cognitive Competencies on Realistic Mathematics Education. Journal on Mathematics Education, 11(1), 17-44. https://doi.org/10.22342/jme.11.1.8690.17-44

Yuliyanti, Winarso, W., \& Misri, M. A. (2019). Analisis Profil Guru Matematika dalam Membangun Konsep Diri Siswa. Jurnal Matematic Paedagogic, III(2), 107-116. https://doi.org/https://doi.org/10.36294/jmp.v3i2.417

Zulfitri, H., Setiawati, N. P., \& Ismaini. (2019). Pendidikan Profesi Guru ( PPG ) sebagai Upaya Meningkatkan Profesionalisme Guru. LINGUA, Jurnal Bahasa \& Sastra, 19(2), 130-136. 